\title{
Kriteria Rumah Tinggal Ideal Bagi Pengrajin Gerabah di Desa Panjangrejo, Kabupaten Bantul, D.I. Yogyakarta
}

\author{
Sidhi Pramudito ${ }^{1}$ dan Yustina Banon Wismarani ${ }^{2}$ \\ 1,2 Program Studi Arsitektur, Fakultas Teknik, Universitas Atma Jaya Yogyakarta \\ ${ }^{1}$ sidhi.pramudito@uajy.ac.id
}

\begin{abstract}
ABSTRAK
Desa Panjangrejo merupakan salah satu desa wisata yang terletak di Kecamatan Pundong, Kabupaten Bantul, Daerah Istimewa Yogyakarta. Desa ini merupakan kawasan sentra produksi kerajinan gerabah dimana hampir sebagian besar penduduk desa tersebut bermatapencaharian sebagai pengrajin gerabah. Potensi tersebut juga didukung oleh Badan Perenancaan dan Pembangunan Daerah (Bappeda) dan Dinas Pariwisata Kabupaten Bantul yang menetapkan desa tersebut menjadi salah satu prioritas penataan dari 7 (tujuh) desa wisata prioritas di Kabupaten Bantul pada tahun 2019. Penelitian tentang kriteria rumah tinggal yang ideal dapat menjadi salah satu langkah awal untuk memahami keinginan dan kebutuhan pengrajin gerabah terhadap rumah tinggal. Tujuan penelitian adalah mengetahui kriteria yang menjadi preferensi responden tentang rumah tinggal yang ideal. Penelitian ini menggunakan pendekatan kualitatif dengan pengumpulan data melalui kuesioner yang dibagikan kepada pengrajin gerabah. Analisis data dilakukan dengan analisis data teks. Hasil analisis menunjukkan bahwa dari berbagai kriteria tentang rumah tinggal yang ideal, ditemukan kriteria yang dominan adalah aspek kesehatan lingkungan rumah, variasi bentuk dan finishing, kebutuhan dan hubungan antar ruang, serta konstruksi bangunan. Hasil penelitian ini diharapkan juga dapat digunakan sebagai masukan untuk Bappeda dan Dinas Pariwisata Kabupaten Bantul apabila di kemudian hari akan melakukan perencanaan dan perancangan di Desa Wisata Panjangrejo.
\end{abstract}

Kata kunci: kriteria perancangan, rumah tinggal ideal, pengrajin gerabah, Desa Panjagrejo

\begin{abstract}
Panjangrejo village is a tourism village that located in Pundong sub-district, Bantul regency, Yogyakarta Special Region. This village is an area of pottery production centers where most of the villagers work as pottery craftsmen. This potential is also supported by the Regional Planning and Development Agency (Bappeda) and the Bantul Regency Tourism Office which establishes the village as one of the priority planning of 7 (seven) priority tourism villages in Bantul Regency in 2019. Research on the criteria of ideal housing can became one of the first steps to understanding the urge and needs of pottery craftsman of houses. The purpose of this study is to determine the criteria that are the preferences of respondents about an ideal houses. This research uses a qualitative approach by collecting data through a questionnaire distributed to pottery craftsmen. Data analysis was performed by text data analysis. The results of the analysis showed that of the various criteria about the ideal houses, the dominant design criteria found were aspects of environmental health of the house, the form and finishing of the house, the spatial needs and relationships, and building construction. The results of this study are also expected to be used as input for Bappeda and the Bantul Regency Tourism Office if in the future they will carry out planning and design in Panjangrejo Tourism Village.
\end{abstract}

Keywords: design criteria, ideal houses, pottery craftsman, Panjagrejo Village

Jurnal RUAS Volume 18 No. 2 Desember 2020 ISSN 1693-3702 E-ISSN 2477-6033 


\section{Pendahuluan}

Manusia sebagai sebuah pribadi tentunya memiliki kebutuhan yang berbeda. Beberapa faktor yang dapat mempengaruhi terbentuknya perbedaan karakteristik manusia antara lain umur, pendidikan, mata pencaharian, tingkat penghasilan, agama, jenis kelamin, dan sebagainya. Dengan adanya perbedaan tersebut, secara tidak langsung akan berpengaruh pada upaya manusia dalam memenuhi kebutuhan dasar hidupnya, salah satunya rumah.

Rumah sebagai tempat tinggal tentunya memiliki peran yang sangat penting bagi berlangsungnya kehidupan manusia. Menurut (Newmark, 1977), terdapat tiga kategori tentang peran rumah sebagai tempat tinggal, antara lain: (1) Rumah sebagai suatu tempat berlindung secara fisik; (2) Rumah sebagai tempat bagi manusia untuk melakukan kegiatan sehari-hari; (3) Rumah sebagai tempat tinggal atau hunian bagi seseorang atau keluarga yang merupakan sebuah lingkungan psiko-sosial. Kehadiran rumah selayaknya tidak hanya berfungsi sebagai pemenuhan kebutuhan fisiologis saja, namun lebih dari itu bahwa rumah juga harus memiliki makna dengan mampu memenuhi kebutuhan psikologis dalam berkegiatan dan berperilaku dengan lingkungannya. Rumah juga diharapkan dapat meningkatkan kesejahteraan penghuni di dalamnya karena akan menunjang pembangunan ekonomi, sosial budaya dan bidang-bidang yang lain (Tutuko, 2008). Definsi yang lain juga menyebutkan bahwa rumah beserta lingkungannya (permukiman) merupakan pusat kegiatan keluarga, pendidikan, pembentukan kepribadian dan nilai budaya suatu komunitas serta sebagai tempat persemaian generasi yang akan datang yang dapat melambangkan peradaban manusia serta dapat menjadi cermin jati diri dan taraf hidup penghuninya sebagai gambaran peri kehidupan dan penghidupan yang menyeluruh (Silas, 1993).

Konsep berhuni (dalam hal ini diwujudkan dalam bentuk rumah) selalu mengalami perubahan dari masa ke masa. Perubahan ini terjadi karena adanya perbedaan karakteristik tiap-tiap manusia atau karena adanya perbedaan atau perubahan konsep dan tujuan dalam sebuah lingkungan tertentu. Dengan kata lain, perubahan dapat terjadi sebagai respon manusia terhadap konteks yang sedang terjadi pada masanya. Respon ini terjadi sebagai bentukan kebudayaan, kebiasaan, maupun latar belakang pengalaman pribadi masing-masing (Putra, 2013).

Sejalan dengan dinamika perubahan dari masa ke masa tersebut, saat ini telah terjadi modifikasi konsep rumah dan permukiman dalam suatu daerah yang dikembangkan menjadi konsep desa wisata. Desa Wisata Panjangrejo merupakan salah satu desa wisata yang terletak di Kecamatan Pundong, Kabupaten Bantul, Daerah Istimewa Yogyakarta. Desa ini juga merupakan salah satu desa yang menjadi prioritas penataan dari 7 (tujuh) desa wisata prioritas di Kabupaten Bantul pada tahun 2019. Desa Wisata Panjangrejo merupakan kawasan sentra produksi kerajinan gerabah dimana hampir sebagian besar penduduk desa wisata tersebut bermatapencaharian sebagai pengrajin gerabah. Kondisi tersebut menyebabkan rumah tinggal beradaptasi menjadi rumah produktif (Home Based Enterprises/HBEs atau Usaha Berbasis Rumah/UBR). HBEs/UBR dapat dideskripsikan sebagai kegiatan untuk menghasilan pendapatan yang memiliki karakteristik lokasi usaha berada di rumah (Strassmann, 1986) dalam (Tyas, 2015). Ruang usaha dan area rumah tangga biasanya saling berbagi atau menyatu untuk meminimalisir proses produksi serta mengatasi masalah kemiskinan (Lawanson, Taibat, \& Olanrewaju, 2012) (Vyas \& Akhlaq., 2012) dalam (Ezeadichie dkk, 2018).

Latar belakang kebutuhan, budaya manusia yang berbeda-beda akan menentukan perilaku dan aktivitas manusia yang berbeda-beda pula. Sebagai akibatnya, berbagai sistem setting ruang yang merupakan penampung sistem aktivitas kelompok-kelompok

Jurnal RUAS Volume 18 No. 2 Desember 2020 ISSN 1693-3702 E-ISSN 2477-6033 
manusia yang berbeda akan mempunyai karakter yang berbeda-beda pula. Perbedaan kelompok manusia yang berakibat pada perbedaan macam aktivitas maupun setting yang dibutuhkan bagi kegiatan tersebut (Rapoport, 1969). Hal ini juga kemudian menjadi kendala utama HBEs/UBR. Kendala utama HBEs/UBR adalah adanya persaingan ruang untuk usaha dengan ruang domestik. Persaingan ruang dalam UBR dapat berupa konflik ruang dan multi-use space (Tipple, 2005). Masalah lain yang muncul dengan adanya HBEs/UBR adalah kegiatan ini dilakukan tanpa memperhitungkan peraturan ketenagakerjaan seperti keselamatan, standar ruang yang tepat, penyediaan ventilasi, pencegahan kebakaran dan evakuasi, pencahayaan siang hari yang disebabkan oleh faktor kemiskinan dari masyarakat tersebut (Huba \& Yohannes, 2015). Dengan adanya adapatasi rumah tinggal menjadi HBEs/UBR sebagai tuntutan fungsi pariwisata di desa tersebut, pada akhirnya berdampak pada munculnya preferensi pengrajin gerabah tentang desain rumah tinggal yang ideal. Preferensi ini muncul dengan harapan dapat tercapat kebutuhan ruang untuk berhuni maupun usaha.

Berdasarkan latar belakang tersebut, preferensi rumah yang ideal untuk setiap orang tentunya akan berbeda-beda (Andoni, 2016). Wujud desain rumah yang ideal tentunya akan sangat dipengaruhi preferensi tiap individu. Preferensi tiap individu sendiri dipengaruhui oleh faktor gaya hidup penghuni sesuai standar hidupnya untuk memenuhi tujuan dari hidupnya. Perbedaan preferensi tiap individu berakibat munculnya perbedaan pada macam preferensi desain sebuah rumah tinggal yang ideal sesuai apa yang dibutuhkan tiap individu. Pemahaman preferensi individu sebagai tahap awal dalam proses desain menjadi penting dan pada akhirnya akan membuka potensi dan konsep baru dalam perencanaan maupun perancangan konsep rumah yang sesuai akan kebutuhan tiap individu.

Preferensi merupakan kecenderungan untuk memilih sesuatu yang lebih disukai dari pada yang lain. Menurut (Porteus, 1977), preferensi merupakan bagian dari komponen pembuat keputusan yang saling mempengaruhi seseorang dalam mengambil keputusan. Komponen tersebut meliputi persepsi, sikap, nilai dan kecenderungan (Nursusandhari, 2009). Studi perilaku individu dapat digunakan oleh ahli lingkungan dan para desainer untuk menilai keinginan pengguna (user) terhadap suatu objek yang akan direncanakan (Porteus, 1977). Dengan melihat preferensi dapat memberikan masukan bagi bentuk partisipasi dalam proses perencanaan.

Preferensi merupakan salah satu studi keperilakuan dalam arsitektur yang memiliki manfaat dalam menjelaskan dan memprediksi perilaku manusia dalam kehidupan sehari-hari sehingga dapat dihasilkan karya-karya yang lebih baik (Canter, 1974) dalam (Sueca dkk, 2001) dalam (Syafrina, 2018). Berkaitan dengan hal tersebut, penelitian ini bertujuan untuk mengetahui kriteria yang menjadi preferensi pengrajin gerabah tentang rumah tinggal yang ideal. Melalui penelitian ini diharapkan dapat menjadi salah satu langkah awal untuk memahami keinginan dan kebutuhan pengrajin gerabah dalam hal rumah tinggal yang ideal. Lebih lanjut, penelitian juga diharapkan dapat digunakan sebagai masukan untuk Bappeda dan Dinas Pariwisata Kabupaten Bantul apabila di kemudian hari akan melakukan perencanaan dan perancangan di Desa Wisata Panjangrejo.

\section{Bahan dan Metode}

Penelitian ini dilakukan secara kualitatif dan bersifat eksploratif dengan menggunakan pendekatan grounded theory. Grounded theory adalah suatu metode penelitian kualitatif yang dilakukan untuk menyusun teori tentang proses, kegiatan, atau interaksi antara orang dengan lingkungan fisik/sosial yang bersumber pada perspektif partisipan. Data dikumpulkan terutama dari wawancara atau kuisioner terbuka tentang 
pengalaman partisipan terhadap proses, kegiatan, atau interaksi; dan aspek-aspek lain yang relevan dengan pengalaman tersebut. Peneliti menghasilkan penjelasan umum (teori) dari suatu fenomena, proses, tindakan atau interaksi yang dibentuk oleh responden (Budiasih, 2014) (Creswell, 2007) dalam (Syafrina dkk, 2018). Data yang terkumpul dianalisis, ditafsirkan, dan disusun dalam bentuk model hipotesis. Perolehan data berupa informasi mengenai aspek-aspek yang menjadi kriteria responden tentang rumah tinggal yang ideal bagi pengrajin gerabah.

Pengumpulan data dilakukan dengan mengambil sampel secara purpossive sampling yaitu mengkategorisasikan bangunan berdasarkan fungsinya (Setiamurdi \& Santosa, 2017) (Mubarrok \& Pramudito, 2018), yaitu rumah tinggal warga pengrajin gerabah. Langkah yang dilakukan dalam pengumpulan data yaitu melalui penyebaran kuesioner dan wawancara. Kuesioner bersifat terbuka (open-ended) yang mana dalam menjawab pertanyaan, responden diminta untuk berpendapat secara bebas dengan harapan jawaban yang akan didapatkan sesuai dengan yang dirasakan, dipikirkan, dan preferensi responden terkait rumah tinggal yang ideal bagi mereka (pengrajin gerabah).

Analisis data yang telah didapat dilakukan dengan metode analisis isi yang dilakukan dalam tiga tahap yaitu open coding, axial coding, dan selective coding (Creswell, 2007). Tahap open coding, merupakan tahap melakukan identifikasi kata kunci dari jawaban responden. Tahap axial coding, merupakan tahap membuat kategori dengan kata yang lebih umum melalui pengelompokan kata kunci yang memiliki kedekatan makna ataupun sifat. Pada tahap ini pengkategorian dilakukan dengan diskusi kelompok agar pemilihan kata tidak bias. Frekuensi dari masing-masing kategori disajikan dalam bentuk diagram melalui analisis distribusi. Tahap selective coding merupakan tahap menyusun model hipotesis berdasarkan kategori-kategori yang didapatkan dari tahap axial coding. Penarikan kesimpulan dari penelitian ini dilakukan dengan mencocokan data yang diperoleh dari data literatur tentang preferensi, definisi dan arti penting rumah tinggal dengan kondisi sebenarnya di lapangan yang pada akhirnya akan menghasilkan sebuah

hipotesis baru yang bersifat umum terkait kriteria rumah tinggal yang ideal bagi pengrajin gerabah.

\section{Hasil dan Diskusi}

\subsection{Data Pengamatan}

Dusun Jetis merupakan dusun dengan jumlah pengrajin gerabah terbanyak diantara dusun-dusun pada Desa Panjangrejo lainnya. Jumlah pengrajin gerabah di Dusun Jetis, Desa Panjangrejo pada tahun 2019 adalah sebanyak 33 (tiga puluh tiga) pengrajin. Berdasarkan sebaran dan jumlah pengrajin gerabah tersebut, maka penulis melakukan distribusi kuisioner. Penyajian data mengenai profil responden sebagai data penunjang terdiri dari jenis kelamin, rentang usia, asal, jumlah anggota keluarga, dan jumlah penghasilan terangkum dalam diagram-diagram berikut: 


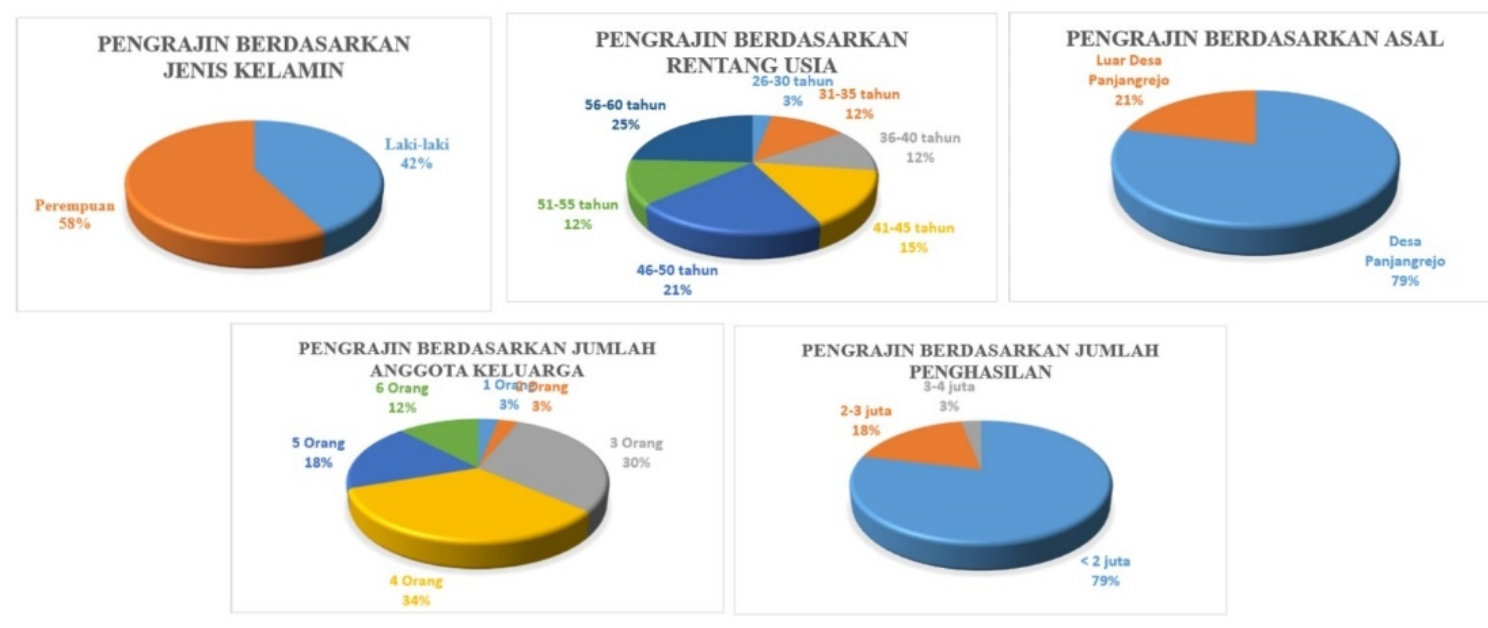

Diagram 1. Histogram Hasil Kuisioner Profil Responden (Sumber: Hasil Analisis, 2020)

Berdasarkan Diagram 1 dapat dideskripsikan bahwa pengrajin gerabah yang masih aktif terdiri dari 14 laki-laki (42\%) dan 19 perempuan (58\%). Berdasarkan data usia pengrajin gerabah, usia pengrajin masih termasuk dalam rentang usia produktif, yaitu usia 15-64 tahun. Jumlah pengrajin yang berada dalam rentang usia produktif tersebut adalah 33 orang (seluruhnya). Usia dengan rentang usia 26-30 tahun berjumlah 1 orang (3\%), usia 31-35 tahun berjumlah 4 orang (12\%), usia 36-40 tahun berjumlah 4 orang $(12 \%)$, usia 41-45 tahun berjumlah 5 orang (15\%), usia 46-50 tahun berjumlah 7 orang (21\%), usia 51-55 tahun berjumlah 4 orang (12\%), dan usia 56-60 berjumlah 8 orang (25\%). Sebagian besar pengrajin gerabah berasal dari Desa Panjangrejo sebanyak 26 orang (79\%), dan dari luar Desa Panjangrejo sebanyak 7 orang (21\%). Jumlah anggota keluarga yang tinggal dalam satu rumah bersama pengrajin gerabah adalah 1-6 orang. Satu rumah yang ditinggali oleh 1 orang sebanyak 1 keluarga (3\%), ditinggali oleh 2 orang sebanyak 1 keluarga (3\%), ditinggali oleh 3 orang sebanyak 10 keluarga (30\%), ditinggali 4 orang sebanyak 11 keluarga (34\%), ditinggali 5 orang sebanyak 6 keluarga (18\%) dan ditinggali 6 orang sebanyak 4 keluarga (12\%). Penghasilan pengrajin gerabah yang kurang dari 2 juta per bulan sebanyak 26 orang (79\%), penghasilan 2-3 juta sebanyak 6 orang (18\%), dan yang berpenghasilan 3-4 juta sebanyak 1 orang (3\%).

Setelah responden melakukan pengisian pertanayaan tertutup mengenai profil responden, kemudian responden diminta untuk mendeskripsikan rumah tinggal yang ideal menurut mereka. Pertanyaan tersebut berbentuk pertanyaan terbuka (open-ended) agar responden dengan leluasa memberikan preferensi mereka tentang rumah tinggal yang ideal.

\subsection{Analisis}

Setelah mengisi pertanyaan tertutup berupa profil responden, tahap analisis isi yang dilakukan adalah analisis pertanyaan terbuka (open-coding) dari jawaban responden mengenai rumah tinggal yang ideal menurut preferensi mereka (pengrajin gerabah). Contoh jawaban pertanyaan terbuka (open-coding) dari jawaban responden dapat dilihat pada beberapa kutipan jawaban berikut. 
Tabel 1. Kutipan Beberapa Jawaban Responden tentang Rumah Tinggal yang Ideal

\begin{tabular}{lll}
\hline No & \multicolumn{1}{c}{ Responden } & \multicolumn{1}{c}{ Jawaban } \\
\hline 1 & $\begin{array}{l}\text { Pengrajin 1 (laki-laki, 50 } \\
\text { tahun) }\end{array}$ & $\begin{array}{l}\text { Tidak digabung untuk bekerja (penggabungan ruangan). Misal, } \\
\text { dapur digunakan untuk memasak sekaligus membuat gerabah. }\end{array}$ \\
\hline 2 & $\begin{array}{l}\text { Pengrajin 2 (perempuan, } \\
\text { 39 tahun) }\end{array}$ & $\begin{array}{l}\text { Ruang kamar mencukupi sesuai kebutuhan anggota keluarga. } \\
\text { Tahan terhadap bencana (kuat). Ada ruangan untuk shalat. }\end{array}$ \\
\hline 3 & $\begin{array}{l}\text { Pengrajin 9 (laki-laki, 50 } \\
\text { tahun) }\end{array}$ & $\begin{array}{l}\text { Menggunakan tembok dan genteng. Punya MCK. Rumah yang } \\
\text { memenuhi kebutuhan penggunanya. }\end{array}$ \\
\hline 4 & $\begin{array}{l}\text { Pengrajin 10 } \\
\text { (Perempuan, 39 tahun) }\end{array}$ & $\begin{array}{l}\text { Rumah yang jauh dari kandang ternak. Lahan luas. Rumah } \\
\text { menggunakan plafon (menghindari debu). }\end{array}$ \\
\hline 5 & $\begin{array}{l}\text { Pengrajin 19 (laki-laki, } \\
\text { 46 tahun) }\end{array}$ & $\begin{array}{l}\text { Rumah yang terpisah dengan rumah produksi. Bersih. Lantai } \\
\text { keramik. Dinding sudah dicat. }\end{array}$ \\
\hline
\end{tabular}

(Sumber: Survei Penulis, 2020)

Berdasarkan beberapa kutipan tersebut, maka didapatkan beberapa kata kunci yang dapat mewakili jawaaban tersebut yakni "ruang tidak digabung", "rumah yang memenuhi kebutuhannya", "rumah terpisah", "menggunakan plafon/ lantai keramik/ dinding dicat, diaci/ bersih", dan "kuat/ tahan terhadap bencana". Temuan kata-kata kunci kemudian dikelompokkan menjadi sub-kategori dan kategori (axial coding). Berdasarkan hasil analisis terhadap data teks ditemukan 8 (delapan) kategori terkait aspek-aspek rumah tinggal yang ideal bagi pengrajin gerabah di Desa Panjangrejo sebagai berikut

\section{Tabel 2. Pengelompokan Sub-Kategori dan Kategori (Axial Coding) tentang Rumah Tinggal yang Ideal bagi Pengrajin Gerabah di Desa Panjangrejo}

\begin{tabular}{|c|c|c|}
\hline Sub-kategori & Jumlah & Kategori \\
\hline Bersih, terhindar dari debu & 14 & \multirow{3}{*}{$\begin{array}{l}\text { Kesehatan Lingkungan } \\
\text { Rumah }(22)\end{array}$} \\
\hline Rumah yang sejuk dan tertutup, ventilasi cukup, nyaman, tidak panas & 5 & \\
\hline Rumah yang sehat, terawat & 3 & \\
\hline Tahan terhadap bencana (kuat) & 5 & \multirow{7}{*}{ Konstruksi bangunan $(13$} \\
\hline Rumah tidak bocor & 2 & \\
\hline Bisa untuk berteduh & 2 & \\
\hline Menggunakan tembok dan genteng & 1 & \\
\hline Memiliki tembok & 1 & \\
\hline Memiliki atap & 1 & \\
\hline Atap rumah yang memadai & 1 & \\
\hline Ruang kamar mencukupi sesuai kebutuhan anggota keluarga & 1 & \multirow{9}{*}{$\begin{array}{c}\text { Kebutuhan dan Hubungan } \\
\text { Ruang (14) }\end{array}$} \\
\hline Ruang yang tersedia sesuai kegiatan yang diwadahi & 3 & \\
\hline Ukuran rumah sesuai kebutuhan anggota keluarga & 1 & \\
\hline Ada ruang untuk shalat & 1 & \\
\hline Ruang khusus untuk kegiatan bersama keluarga & 1 & \\
\hline $\begin{array}{l}\text { Tidak digabung untuk bekerja (penggabungan ruangan). Misal dapur } \\
\text { digunakan untuk memasak sekaligus membuat gerabah }\end{array}$ & 1 & \\
\hline $\begin{array}{l}\text { Rumah tinggal terpisah dengan rumah produksi agar aktivitas di } \\
\text { rumah tidak terganggu }\end{array}$ & 1 & \\
\hline Rumah yang jauh dari kandang ternak & 1 & \\
\hline Rumah yang terpisah dengan rumah produksi & 4 & \\
\hline Luas & 6 & Ukuran ruang (6) \\
\hline Dindingnya halus (sudah dicat, bukan plesteran atau acian) & 4 & \multirow{7}{*}{$\begin{array}{l}\text { Variasi Bentuk dan } \\
\text { finishing rumah (19) }\end{array}$} \\
\hline Tingkat & 2 & \\
\hline Sederhana & 1 & \\
\hline Lantai keramik & 5 & \\
\hline Memiliki plafon & 3 & \\
\hline Rapi & 3 & \\
\hline Seperti rumah-rumah di kota & 1 & \\
\hline Strategis secara lokasi & 2 & \multirow{2}{*}{$\begin{array}{l}\text { Lokasi dan aksesibilitas } \\
\text { (3) }\end{array}$} \\
\hline Berada di pinggir jalan & 1 & \\
\hline Kamar mandi di dalam & 1 & \multirow{2}{*}{ Prasarana (4) } \\
\hline Ada sanitasi air bersih & 1 & \\
\hline
\end{tabular}




\begin{tabular}{|c|c|c|}
\hline Sub-kategori & Jumlah & Kategori \\
\hline Punya MCK & 1 & \\
\hline WC memadai & 1 & \\
\hline Rumah yang aman & 5 & \multirow{2}{*}{ Keamanan (6) } \\
\hline Serangga tidak masuk ke dalam rumah & 1 & \\
\hline
\end{tabular}

(Sumber: Analisis Penulis, 2020)

Perolehan kategori memiliki frekuensi yang dianalisis menggunakan analisis distribusi. Hasil analisis distribusi menunjukkan bahwa preferensi rumah tinggal yang ideal cenderung dipengaruhi oleh faktor kesehatan lingkungan rumah, bentuk dan finishing, kebutuhan dan hubungan ruang, konstruksi bangunan, ukuran ruang, keamanan, prasarana, serta lokasi dan aksesibilitas. Kategori faktor yang paling dominan muncul yaitu faktor kesehatan lingkungan rumah sebesar 22 (24\%), kemudian bentuk dan finishing sebesar 19 (21\%). Faktor dominan yang hampir berjumlah sama yaitu kebutuhan dan hubungan ruang sebesar 14 (16\%) dan konstruksi bangunan sebesar 13 (15\%). Faktor yang paling kecil adalah faktor ukuran ruang sebesar 6 (7\%), faktor keamanan sebesar 6 (7\%) dan faktor prasarana dan lokasi aksesibilitas yang masing-masing sebesar 4 (5\%). Hasil analisis distribusi kategori preferensi rumah tinggal yang ideal dapat dilihat pada Diagram 2.

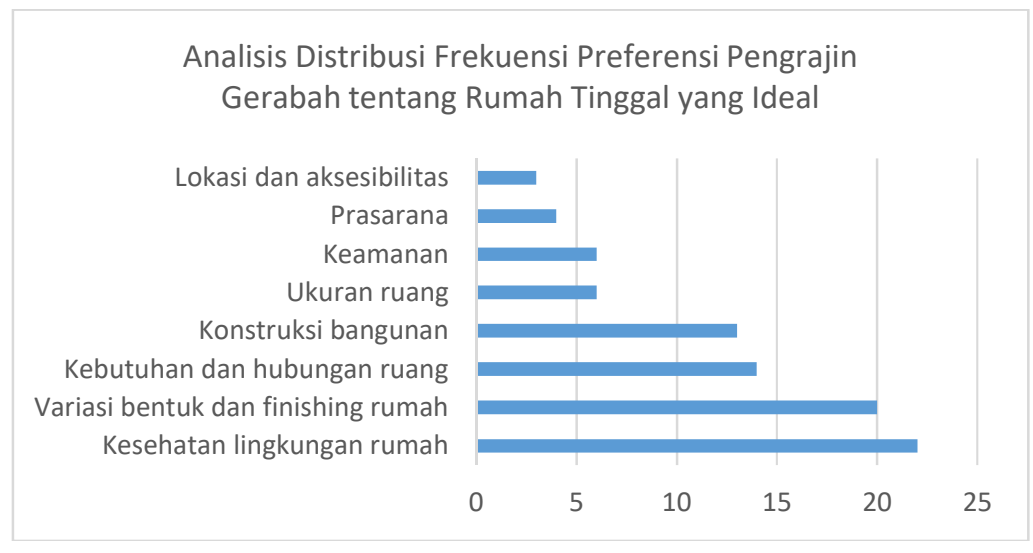

Diagram 2. Analisis Distribusi Frekuensi Preferensi Pengrajin Gerabah tentang Rumah Tinggal yang Ideal (Sumber: Hasil Analisis, 2020)

\subsubsection{Analisis Kategori Faktor Dominan 1: Kesehatan Lingkungan Rumah}

Faktor kesehatan lingkungan menjadi faktor dominan atau menempati urutan pertama dalam preferensi pengrajin gerabah terhadap rumah tinggal yang ideal. Kategori ini diungkapkan oleh 22 pengrajin gerabah. Dalam faktor kesehatan lingkungan rumah ini, responden mengungkapkan bahwa aspek rumah yang bersih merupakan hal utama yang harus dipenuhi sebagai kriteria rumah tinggal yang ideal, dimana responden mengungkapkan bahwa rumah tinggal harus terawat dan terhindar dari debu. Selain itu, aspek rumah yang sejuk dengan penghawaan alami juga merupakan kriteria yang juga harus dipertimbangkan dimana rumah yang ideal harapannya memiliki ventilasi yang cukup agar rumah terasa sejuk. Kriteria tersebut dapat terlihat dari beberapa jawaban dari responden (pengrajin gerabah) berikut.

"Rumah yang bersih." (pengrajin 29, pengrajin 33)

"Rumah yang sejuk dan tertutup, terhindar dari debu." (pengrajin 11) 
"Rumah yang sehat, memiliki ventilasi." (pengrajin 16)

"Rumah yang sejuk." (pengrajin 26)

"Rumah yang sehat, nyaman dan tidak panas." (pengrajin 27)

Berdasarkan analisis terhadap data teks tersebut, maka dapat dilihat bahwa terdapat 2 (dua) aspek dominan dalam kategori kesehatan lingkungan rumah yaitu rumah yang bersih sebesar 15 (68\%) dan rumah yang sejuk dengan penghawaan alami sebesar 7 (32\%) (Diagram 3).

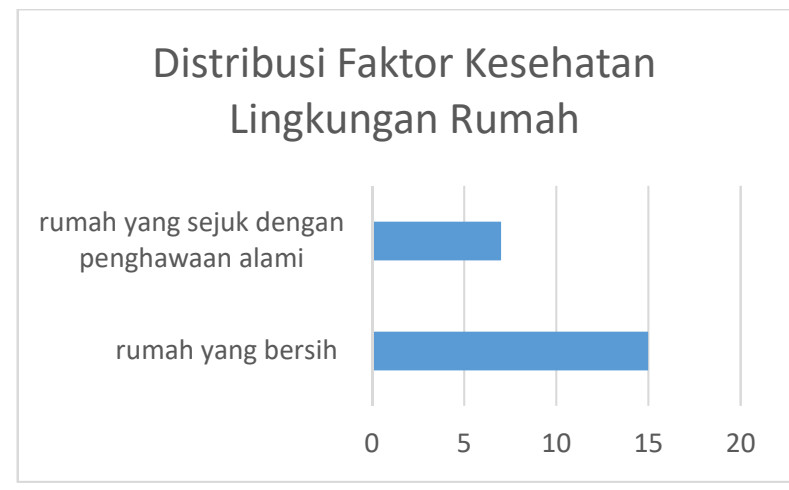

Diagram 3. Analisis Distribusi Frekuensi Faktor Kesehatan Lingkungan Rumah (Sumber: Hasil Analisis, 2020)

\subsubsection{Analisis Kategori Faktor Dominan 2: Variasi Bentuk dan Finishing Rumah}

Faktor bentuk dan finishing rumah menjadi faktor dominan yang kedua dalam preferensi pengrajin gerabah terhadap rumah tinggal yang ideal. Hal ini dapat terlihat dari jawaban yang diungkapan responden sejumlah 20. Dalam faktor bentuk dan finishing rumah ini, responden mengungkapkan bahwa aspek kelengkapan dan fisnishing elemen rumah merupakan salah satu hal yang harus dipertimbangkan sebagai kriteria rumah tinggal yang ideal. Aspek finishing rumah ini diwakili dari ungkapan responden bahwa sebuah rumah sebaiknya memiliki kelengkapan-kelengkapan pada setiap elemen pembentuk rumah, seperti lantai yang dikeramik, dinding yang diaci dan dicat, dan memiliki penutup langit-langit (plafon). Aspek lain yang menjadi pertimbangan adalah aspek ragam bentuk rumah, dimana responden mengungkapkan bahwa rumah dirancang sebaiknya rapi, dengan bentuk yang sederhana atau tingkat (aspek ini sangat variatif). Kriteria tersebut dapat terlihat dari beberapa jawaban dari responden (pengrajin gerabah) berikut.

"Dindingnya halus (sudah dicat, bukan plesteran atau acian)." (pengrajin 4)

"Rumah dengan dinding diaci, lantai keramik." (pengrajin 11)

"Sederhana, lantai keramik, dinding sudah dicat." (pengrajin 20)

"Rumah rapi dan tingkat." (pengrajin 28)

"Atap rumah dibuat bagus dan rapi, dan memiliki plafon." (pengrajin 32)

Berdasarkan analisis terhadap data teks tersebut, maka dapat dilihat bahwa terdapat 2 (dua) aspek dominan dalam kategori variasi bentuk dan finishing rumah yaitu kelengkapan dan finishing elemen rumah sebesar 13 (65\%) dan ragam bentuk rumah sebesar 7 (35\%) (Diagram 4). 


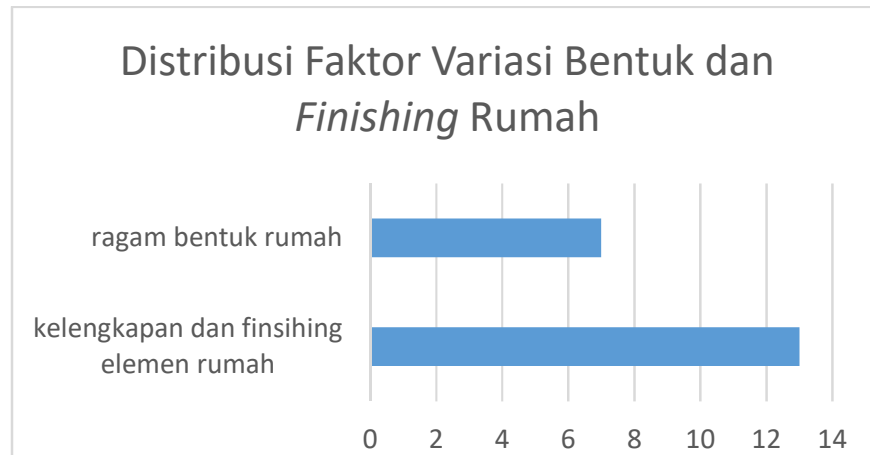

Diagram 4. Analisis Distribusi Frekuensi Faktor Variasi Bentuk dan Finishing Rumah (Sumber: Hasil Analisis, 2020)

\subsubsection{Analisis Kategori Faktor Dominan 3: Kebutuhan dan Hubungan Ruang}

Selain 2 (dua) faktor yang telah disebutkan pada bagian sebelumnya, faktor dominan ketiga yang menjadi kriteria rumah tinggal yang ideal bagi pengrajin gerabah adalah kebutuhan dan hubungan ruang. Kategori ini diungkapkan oleh 14 pengrajin gerabah. Aspek pertama yang perlu diperhatikan pada faktor ini adalah ruang sesuai jenis kegiatan yang diwadahi sehingga harapannya kegiatan yang sedang berlangsung tidak saling mengganggu baik kegiatan rumah tangga maupun kegiatan pengrajin gerabah. Hal tersebut sejalan dengan apa yang diungkapkan responden seperti diperlukan adanya ruang khusus untuk kegiatan bersama keluarga, dan rumah yang terpisah dengan tempat produksi. Selain itu, aspek lain yang perlu diperhatikan yaitu terkait kapasitas ruang yang sesuai dengan pelaku. Hal tersebut berdasarkan dari ungkapan responden bahwa ukuran ruangan harus mencukupi sesuai kebutuhan anggota keluarga. Kriteria tersebut dapat terlihat dari beberapa jawaban dari responden (pengrajin gerabah) berikut.

“Tidak digabung untuk bekerja (penggabungan ruangan)." (pengrajin 1)

"Rumah yang jauh dari kandang ternak." (pengrajin 10)

"Ukuran rumah sesuai jumlah anggota keluarga." (pengrajin 12)

"Ruang yang tersedia sesuai kegiatan yang diwadahi." (pengrajin 12)

"Rumah yang terpisah dengan rumah produksi." (pengrajin 17)

Berdasarkan analisis terhadap data teks tersebut, maka dapat dilihat bahwa terdapat 2 (dua) aspek dominan dalam kategori kebutuhan dan hubungan ruang yakni ruang sesuai jenis kegiatan yang diwadahi sebesar 12 (86\%) dan kapasitas ruang yang sesuai sebesar 2 (14\%) (Diagram 5).

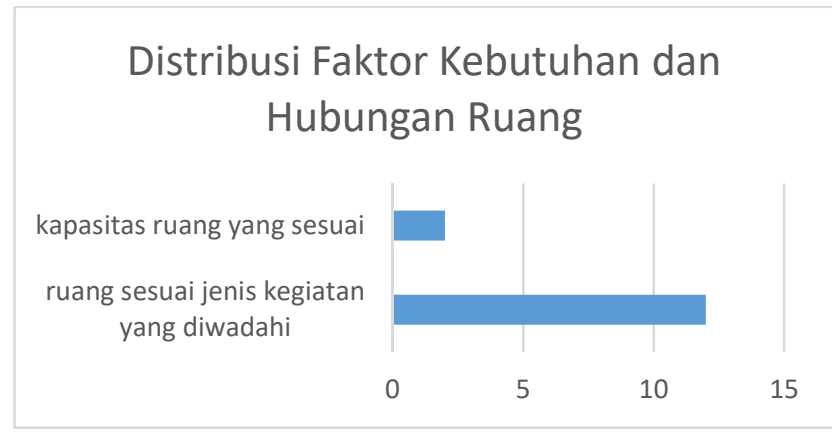

Diagram 5. Analisis Distribusi Frekuensi Faktor Kebutuhan dan Hubungan Ruang (Sumber: Hasil Analisis, 2020) 


\subsubsection{Analisis Kategori Faktor Dominan 4: Konstruksi Bangunan}

Faktor konstruksi bangunan rumah menjadi faktor dominan yang keempat dalam preferensi pengrajin gerabah terhadap rumah tinggal yang ideal. Hal ini dapat terlihat dari jawaban yang diungkapan responden sejumlah 13. Dalam faktor konstruksi bangunan rumah tinggal, responden mengungkapkan bahwa aspek tahan bencana merupakan salah satu aspek yang harus diperhatikan juga. Aspek tahan bencana ini diwakili dari ungkapan responden bahwa sebuah rumah sebaiknya kuat, tahan dari bencana, dan tidak bocor. Selain itu, aspek lain yang perlu diperhatikan yakni terkait kondisi disik rumah. Hal tersebut berdasarkan dari ungkapan responden bahwa secara fisik rumah harus memiliki tembok dan atap yang memadai. Kriteria tersebut dapat terlihat dari beberapa jawaban dari responden (pengrajin gerabah) berikut.

"Tahan terhadap bencana (kuat)." (pengrajin 2)

"Menggunakan tembok dan genteng." (pengrajin 9)

"Atap rumah yang memadai." (pengrajin 31)

Berdasarkan analisis terhadap data teks tersebut, maka dapat dilihat bahwa terdapat 2 (dua) aspek dominan dalam kategori konstruksi bangunan yakni tahan bencana sebesar 8 (62\%) dan kondisi fisik rumah sebesar 5 (48\%) (Diagram 6).

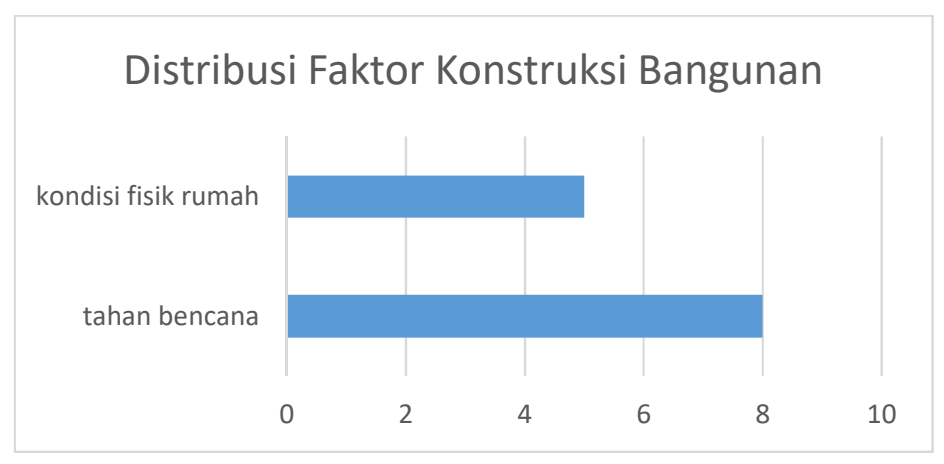

Diagram 6. Analisis Distribusi Frekuensi Faktor Konstruksi Bangunan

(Sumber: Hasil Analisis, 2020)

\subsection{Diskusi}

Dari hasil analisis di atas, diperoleh 4 (empat) faktor dominan yang menjadi preferensi pengrajin gerabah terhadap rumah tinggal yang ideal yaitu kesehatan lingkungan rumah (F:22), variasi bentuk dan finishing rumah (F:20), kebutuhan dan hubungan ruang (F:14), serta konstruksi bangunan (F:13). Apabila melihat dari sub kategori, maka sub kategori yang memiliki frekuensi distribusi yang cuku dominan adalah rumah yang bersih sebesar (F:15), kelengkapan dan finishing elemen rumah (F:13), ruang sesuai jenis kegiatan yang diwadahi (F:12), dan tahan bencana (F:8). Keempat faktor tersebut apabila disusun dalam diagram model hipotesis, maka akan terlihat faktor, kategori, dan sub kategori mana yang semakin dominan (lihat Diagram 7). 


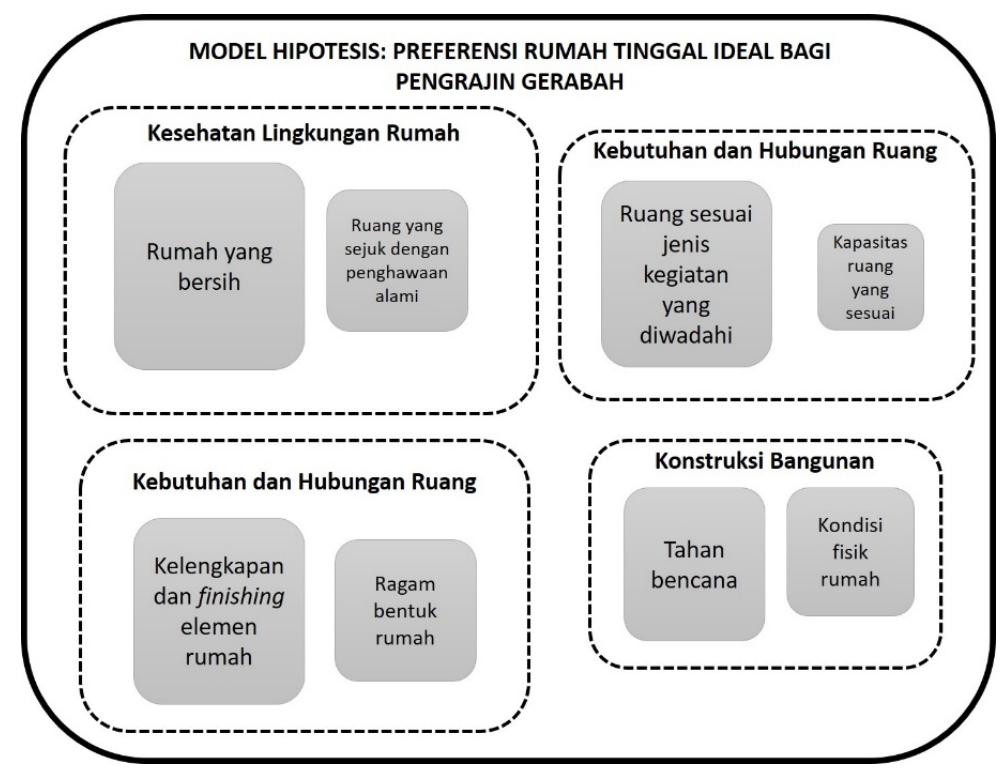

Diagram 7. Model Hipotesis: Preferensi Rumah Tinggal Ideal bagi Pengrajin Gerabah (Sumber: Hasil Analisis, 2020)

Selain keempat faktor tersebut, ditemukan faktor lain yang juga dapat dijadikan pertimbangan dalam merancang rumah tinggal yang ideal bagi pengrajin gerabah di Desa Panjangrejo. Faktor ini dapat dikatakan sebagai faktor sekunder. Berdasarkan hasil analisis pengelompokan sub-kategori dan kategori (axial coding) yang telah dilakukan faktor-faktor tersebut adalah ukuran ruang (F:6), keamanan (F:6), prasarana (F:4), serta lokasi dan aksesibilitas (F:3). Faktor-fator tersebut tercatat dengan persentase sebesar 3-7\% (lihat Gambar 1).

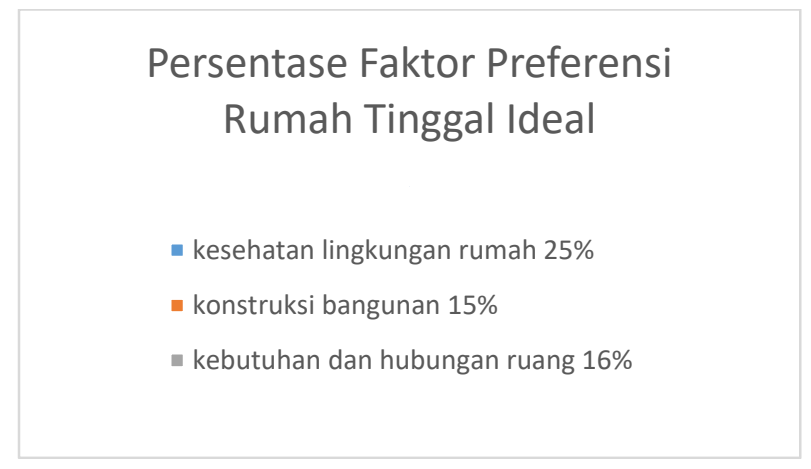

Gambar 1. Persentasi Faktor Preferensi Rumah Tinggal Ideal bagi Pengrajin Gerabah

(Sumber: Hasil Analisis, 2020)

Berdasarkan analisis data teks, faktor ukuran ruang terdiri dari aspek rumah dengan ukuran yang luas. Hal tersebut muncul karena terdapat kendala pada faktor kebutuhan dan hubungan ruang, dimana kegiatan yang terjadi dalam rumah tinggal eksisting masih saling bercampur. Faktor keamanan terkait dengan jawaban responden yang menyatakan bahwa rumah sebaiknya aman baik dari manusia maupun hewan (serangga). Faktor ini muncul karena ada kendala pada faktor kebersihan, konsruksi bangunan, serta variasi bentuk dan finishing rumah tinggal. Tata ruang pada rumah tinggal yang masih bercampur, serta tuntutan kegiatan produksi menyebabkan bentuk rumah yang ada cenderung tambal sulam. 

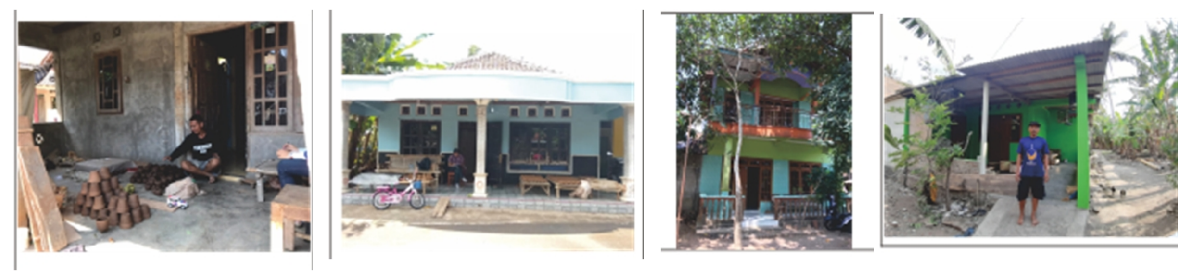

Gambar 2. Beberapa Ragam Kondisi Bentuk Rumah Pengrajin Gerabah (Sumber: Dokumentasi Penulis, 2019)

Faktor prasarana apabila dilihat dari jawaban responden berkaitan dengan kelengkapan fasilitas yang ada di rumah khususnya adanya MCK, sanitasi air yang bersih. Hal ini muncul karena ada kendala pada faktor kebutuhan dan hubungan ruang dalam rumah. Sedangkan faktor lokasi dan aksesibilitas berkaitan dengan lokasi rumah tinggal yang strategis, berada di pinggir jalan, karena terkait dengan rumah yang juga berfungsi sebagai ruang usaha agar terlihat secara visual oleh pengunjung desa wisata.

\section{Simpulan}

Rumah tinggal yang ideal menjadi sangat berarti bagi setiap keluarga yang tinggal di dalamnya, khususnya keluarga pengrajin gerabah. Bagi pengrajin gerabah, arti penting rumah tinggal selain untuk memenuhi kebutuhan dasar, rumah tinggal juga dapat menjadi cermin jati diri dan taraf hidup penghuninya sebagai gambaran peri kehidupan dan penghidupan yang menyeluruh (Silas, 1993). Rumah tinggal dan lingkungannya diharapkan mampu menjadi tempat kegiatan komunitas keluarga serta mampu mendukung pengkehidupan dan penghidupan untuk masa yang akan datang (Tutuko, 2008).

Teori mengenai rumah tinggal yang juga digunakan untuk kegiatan Usaha Berbasis Rumah (UBR) menjelaskan bahwa kendala utama UBR adalah adanya persaingan ruang untuk usaha dengan ruang domestik. Persaingan ruang dalam UBR dapat berupa konflik ruang dan multi-use space (Tipple, 2005). Dengan adanya UBR, ruang-ruang domestik menjadi berkurang karena memang keinginan keluarga untuk meningkatkan penghasilan melalui UBR (Tipple, Settlement Upgrading and Home-Based Enterprises: Discussions from Empirical Data, 2004) dalam (Arisngatiasih, 2015).

Berdasarkan teori tersebut dan apabila dikaitkan dengan hasil analisis preferensi rumah tinggal yang ideal bagi pengrajin gerabah yang telah dilakukan, hampir sebagian besar kategori, sub-kategori, dan faktor yang dominan bertujuan untuk menyelesaikan kendala persaingan ruang usaha dan ruang rumah tangga. Faktor kesehatan lingkungan rumah dengan aspek rumah yang bersih menempati urutan pertama dari keseluruhan faktor dominan. Hal ini jika dapat dilihat hubungannya adalah pencapaian kebersihan rumah menjadi sangat penting karena selama ini banyak rumah tinggal pengrajin gerabah yang masih belum memiliki elemen kelengkapan rumah, penggunaan ruang yang masih saling bercampur serta kapasitas ruang yang belum memadai untuk berkegiatan (faktor dominan ketiga: kebutuhan dan hubungan ruang). Kondisi geografis juga berpengaruh pada munculnya preferensi. Sebagai daerah yang rawan gempa, responden tentunya menginginkan rumahnya tahan terhadap bencana alam (faktor dominan keempat: konstruksi bangunan). Sedangkan untuk faktor dominan yang kedua yakni variasi bentuk dan finishing rumah merupakan faktor yang distribusinya sangat bervariasi. Perbedaan 
preferensi bentuk dan finsihing rumah dapat disebabkan karena adanya perbedaan kondisi sosial ekonomi, budaya, serta pengalaman tentang rumah tinggal sebelumnya.

Apabila ditinjau lebih ke dalam hal yang lebih mendasar lagi, preferensi tentang rumah tinggal yang ideal juga sangat berkaitan dengan teori hierarchy of need yang disampaikan oleh Abraham Maslow, yakni rumah tidak lagi berfungsi untuk memenuhi kebutuhan dasar dan tempat berlindung saja, namun rumah tinggal juga dapat digunakan untuk memenuhi kebutuhan akan penghargaan dan penghormatan diri (selfesteem needs) atau bahkan kebutuhan akan perwujudan diri (self-actualisation needs) (Tutuko, 2008). Hal ini juga selaras dengan pernyataan rumah tinggal juga dapat melambangkan peradaban manusia serta dapat menjadi cermin jati diri dan taraf hidup penghuninya (Silas, 1993). Sebagai saran, penelitian ini dapat dilanjutkan dengan menarik hubungan preferensi dengan profil responden terkait hubungannya dengan usia, asal pengrajin, jumlah penghasilan, maupun jumlah keluarga. Hal ini bertujuan agar hasil rancangan yang akan datang dapat lebih spesifik dan sesuai dengan apa yang diinginkan.

\section{Ucapan Terima Kasih}

Penulis mengucapkan terima kasih kepada Bappeda Kabupaten Bantul atas kesempat yang diberikan bagi penulis untuk melakukan penelitian ini, LPPM UAJY atas pendanaan internal untuk penelitian ini, seluruh Perangkat Desa Panjangrejo dan Pengelola Desa Wisata Gerabah Panjangrejo atas kesempatan yang diberikan, dan kepada asisten penelitian (mahasiswa S1 Program Studi Arsitektur UAJY) yang membantu kelancaran dalam pelaksanaan penelitian ini (Apolinaris Primeracrisa, Sharon Laurensia, Ancilla Dona, dan Bernadetha Indah).

\section{Daftar Pustaka}

Andoni, H. (2016). Preferensi Hunian yang Ideal Bagi Pekerja dan Mahasiswa pada Kelompok Umur Dewasa Awal / Early Adulthood . TEMU ILMIAH IPLBI 2016 (pp. D 129-D 134). Malang: IPLBI.

Arisngatiasih, M. M. (2015). Pola Pemanfaatan Ruang pada Usaha Berbasis Rumah (UBR) di Klaster Batik Jenggot Kota Pekalongan. Jurnal Wilayah dan Lingkungan, 3(3), 175188.

Budiasih, I. G. (2014, Januari). Metode Grounded Theory Dalam Riset Kualitatif. Jurnal Ilmiah Akuntansi dan Bisnis, 9(1), 19-27.

Canter, D. (1974). Psychology for Architect. London: Applied Science Publishers Ltd.

Creswell, J. W. (2007). Qualitative Inquiry and Research Design: Choosing Among Five Approaches. California : Sage Publications, Inc. .

Ezeadichie, N. H., Jiburum, U., Onodugo, V. A., Agatha, C., \& Kingsley, A. (2018). Integrating Home-Based Enterprises in Urban Planning: A Case for Providing Economic Succour for Women of Global South. Berkeley Planning Journal, 82-101.

Huba, N., \& Yohannes, K. (2015). Space Use and Environmental Effects of Home-Based Enterprises. The Case of Buguruni Mnyamani Informal Settlement, Dar Es Salaam, Tanzania. International Journal of Humanities and Social Science, 7-19.

Lawanson, Taibat, \& Olanrewaju, D. (2012). The Home as Workplace: Investigating Home Based Enterprises in Low Income Settlements of the Lagos Metropolis. 48th ISOCARP Congress (pp. 10-13). Russia: ISOCARP Congress.

Mubarrok, N. Z., \& Pramudito, S. (2018). A Study of Façade Elements on Jengki Architecture in Yogyakarta. The 1st International Conference on Cultural Communication and Space (ICCCS) and the 9th International Conference on International Society for

Jurnal RUAS Volume 18 No. 2 Desember 2020 ISSN 1693-3702 E-ISSN 2477-6033 
Vernacular Settlement (ISVS): Reframing the Vernacular: Politics, Semiotics and Representation (pp. 2.1-9). Denpasar: Udayana University Press.

Newmark, T. a. (1977). Self, Space and Shelter: An Introduction to Housing. New York: Harper and Row Publizer Inc.

Nursusandhari, E. (2009). Persepsi, Preferensi, dan Willingness to Pay Masyarakat terhadap Lingkungan Pemukiman Sekitar Kawasan Industri (Kasus Kawasan Industri di Kelurahan Utama, Cimahi, Jawa Barat. Bogor: Institut Pertanian Bogor.

Porteus, J. (1977). Environment and Behavior Planning and Everyday Urban Life. Boston: Addison-Wesley.

Putra, G. B. (2013). Kriteria Dominan Rumah Tinggal Impian. TEMU ILMIAH IPLBI 2013 (pp. A 21-A 24). Makasar: IPLBI.

Rapoport, A. (1969). House Form and Culture Foundation of Cultural Georaphy Series. USA: Prentice-Hall.

Setiamurdi, R. U., \& Santosa, H. (2017). Karakteristik Fasade Bangunan Kawasan Pasar Besar Kota Malang. Jurnal Mahasiswa Arsitektur Universitas Brawijaya.

Silas, J. (1993). Housing Beyond Home: Case Study of Surabaya. Surabaya: ITS.

Strassmann, P. (1986). Types of Neighbourhood and Home-Based Enterprises: Evidence from Lima, Peru. Urban Studies, 485-500.

Sueca, N. P., Primayatna, I. B., S, K. M., Nada, W., \& Wastika, D. N. (2001). Faktor-Faktor Determinan Pengetahuan dan Persepsi Masyarakat Tentang Bangunan Berlanggam Bali. Dimensi Teknik Arsitektur, 157-164.

Syafrina, A., Angela C. T., Suhendri, Nunik H., Hanson E. K. (2018). Preferensi Masyarakat tentang Lingkungan Perumahan yang Ingin Ditinggali. RUAS, 16(1), 32-45.

Tipple, A. G. (2004). Settlement Upgrading and Home-Based Enterprises: Discussions from Empirical Data. Cities, 21(5), 371-379. doi:10.1016/j.cities.2004.07.006

Tipple, A. G. (2005). The Place of Home-based Enterprises in the Informal Sector: Evidence from Cochabamba, New Delhi, Surabaya and Pretoria. Urban Studies, 42(4), 611632.

Tutuko, P. (2008). https://www.researchgate.net/publication /202719359_Permukiman_Rumah_Produktif_dan_Perkembangannya. Retrieved from https://www.researchgate.net/.

Tyas, W. P. (2015). Home-based enterprises approach for post disaster housing: learnt from post disaster redevelopment programme in developing countries. CITIES 2015 International Conference, Intelligent Planning Towards Smart Cities Procedia - Social and Behavioral Sciences (pp. 139-145). Surabaya: Elsevier.

Vyas, A., \& Akhlaq., A. (2012). Women's Work and Globalisation: A Bibliography (19902011). New Delhi: Centre For Women's Development Studies. 